Volume-V, Issue-02, July-December, 2010

\title{
Enhancement of Retail Banking Operation of Commercial Banks in Bangladesh
}

\author{
FARJANA YESHMIN ${ }^{1}$ \\ MAHMUDA NASRIN $^{2}$
}

\begin{abstract}
People are always concerned about the improvement of their standard of living. In respect of this awareness, financial institutions of Bangladesh specially banking sectors are trying to expand their service net. And in this regard banking sector is playing a tremendous role through Retail Banking (RB). Toward the community development, $R B$ has further enlarged its' position as a major channel of business. RB has taken the foremost funding responsibility as well as commitment to give fast forwarding service to the community through increasing branche, alternative delivery channels, premier banking services. In this study the authors have selected 28 listed banks which covered 59.57\% of listed financial institutions in stock exchange. The study has revealed that during the period of 2006-2008 the sample banks have offered different types of retail products (deposits increased by $88.18 \%$, loan products increased by $48.50 \%$, and cards service by $21.15 \%$ ) by increasing number of branches by 19.28\%.The authors have segmented the article into four parts Firstly an overview of $R B$, secondly, review of previous studies done in this area, thirdly a comparative analysis of data and itss findings and finally conclusive remarks and policy implications.
\end{abstract}

Keywords: Retail banking, Deposit Scheme, Loan, Card service, Delivery channels.

\section{RETAIL BANKING-AN OVERVIEW}

As a driving force of modern economic development, as a pioneer of financial institutions bank is extending its activities from traditional banking toward community oriented services. Now-a-days people are very much concerned about enhancement of their standard of living with their limited earnings. By considering

1 Assistant Professor, Department of Business Administration (Accounting), Stamford University Bangladesh, 51, Siddeswari Road, Dhaka-1217.

2 Lecturer, Department of Business Administration (Accounting), Stamford University Bangladesh, 744 Satmasjid Road, Dhanmondi, Dhaka-1209 
this behaviour pattern of people, banking sector especially private one is expanding their services horizon toward community based services through Retail Banking (RB).

Retail banking is the banking services that are offered to individual customers through local branches of the bank. Examples of retail banking services include checking and savings accounts, credit cards, personal lines of credit, mortgages, and so forth. Some retail banks offer basic brokerage services, though this is not always the case. Retail banking contrasts with commercial banking, which primarily offers services to businesses [http://financial-dictionary.the freedictionary.com/Retail+ Banking]. Retail banking is the cluster of products and services that banks provide to consumers and small businesses through branches, the Internet, and other channels. Consumers and small businesses are typically the core retail banking customers. The key retail banking products are consumer credit and small business loans. Consumer credit includes credit cards, mortgages, home equity lending, auto loans, education loans, and other personal loans. Although loans and deposits are the primary products, retail banking units provide a range of other financial services to consumers and small businesses. Consumers and small businesses constitute a coherent customer group largely because of commonalities in the financial products and services they use. Furthermore, consumers and small businesses are both well served through the branch network [Clark et.al.,2007].

Stability of retail-related activities is typically attributed to several factors. Firstly, retail banking is fundamentally a consumer-based business. The resilience of the consumer sector in recent years has almost certainly contributed to the stability of retail banking. And second important factor in the stability of retail banking is that it serves a large number of small customers. The banking sector especially the private sector banks made meaningful progress and growth in terms of significant market share of deposits and advances through improved customer services, introduction of new products and switching over online banking keeping pace with the globalization process.

The issue of retail banking is extremely important and relevant. Across the globe, retail lending has been a spectacular innovation in the commercial banking sector in recent years. The growth of retail lending, especially, in emerging economies, is attributable to the rapid advances in information technology, the evolving macroeconomic environment, financial market reform, and several microlevel demand and supply side factors. In this study the authors have tried to focus on the enhancement of Retail Banking of commercial banks in Bangladesh. 


\section{PREVIOUS STUDIES ON RETAIL BANKING}

In the mid-1980s, the Business Week reviews focused on the need for banks to generate new revenue streams and enter new markets (for example, securities, investment banking, and insurance) as a way to counter the negative effect of increased competition and disintermediation within traditional RB.

The mid-1990s, however, marked the emergence of the "new retail" model that emphasized alternative retail delivery channels such as telephone call centers, ATMs, and electronic delivery through the emerging Internet (Business Week 1994). Electronic delivery, in particular, was seen as a low-cost alternative to high-cost branches. The use of information-rich computer systems has significantly affected competition within the retail banking industry. The advent of telephone banking, however, and the growing importance of relational databases and credit scoring systems (Leyshon et al. 1998; Leyshon and Thrift 1999), has served to make the retail banking market more competitive. In terms of product delivery, banks are moving away from a reliance on branches to a 'multi-channel' system, where in branches are but one important (and expensive) option (Pollard 1996).

The prospect of Retail Banking is increasing nowadays because it is fundamentally a customer based business and it serves a large number of small customers (individuals and business). The resilience of the consumer sector in recent years has almost certainly contributed to the stability and growth of RB. In $\mathrm{RB}$, products or services respond differently as market conditions change. Banks are also devoting themselves to undertaking much more sophisticated market research to fine tune the packaging and delivery of investment-related financial products to different income and age groups in different geographic areas (Leyshon and Thrift 1999; Smith 1993; Talmor 1994; Casettari 1994). Customer adoption is a recognized dilemma for the strategic plans of financial institutions. Several studies have investigated why individuals choose a specific bank. Important consumer selection factors include convenience, service facilities, reputation and interest rates (Kennington et al., 1996; Zineldin, 1996). According to Delvin (1995), customers have less time to spend on activities such as visiting a bank and therefore want a higher degree of convenience and accessibility. Even traditional channels of vertical mobility in banks are being eroded and new lines of horizontal segmentation between jobs in computer and lending divisions - are taking shape, limiting mobility for workers (Cressey and Scott 1992, Pollard 1995).

DeYoung and Rice (2004) show that "traditional" and "community" banks (defined as those with relatively high core deposit ratios) have a relatively low volatility of revenue, as do "nontraditional" banks (which include a wide range of large banks). There is a need for constant innovation in retail banking. In bracing for 
tomorrow, a paradigm shift in bank financing through innovative products and mechanisms involving constant up-gradation and revalidation of the banks' internal systems and processes is called for. Banks now need to use retailing as a growth trigger. This requires product development and differentiation, innovation and business process reengineering, micro-planning, marketing, prudent pricing, customisation, technological up-gradation, home / electronic / mobile banking, cost reduction and cross-selling (Gopinath, 2005). In annual reports and other financial statements, large commercial banks frequently report results for retail-oriented business segments that include consumer deposit-taking and lending and small business financial services. Hirtle and Stiroh (2005) proposed a broad definition of retail banking that encompasses deposit taking, lending, and other financial services provided to consumers and small business through all delivery channels, including branches, loan offices, call centers, and the internet. Their definition encompasses national consumer credit business.

From "World Retail Banking Report" (Holland, March 28 $8^{\text {th }}$, 2007) it is seen that the average price paid for banking services by active users now stands at $€ 77$ globally, a decrease of $0.3 \%$ since last year. However this global stability hides price variations, which are strikingly different across the world, from a $1.8 \%$ decrease in the Europe Euro zone to a $2.9 \%$ increase in Asia Pacific.

Global banks are involved in international lending and foreign currency trading, in addition to the more typical banking services. Regional banks have numerous branches and automated teller machine (ATM) locations throughout areas that provide banking services to individuals. Banks have become more oriented toward marketing and sales. Community banks are based locally and offer more personal attention. In recent years, online banks-which provide all services entirely over the Internet-have entered the market, and some formerly Internet-only banks are opting to open branches (Ahmad, Khanal, 2007). Bertrand Lavayssiere, managing Director, Global Financial Services at Cap Gemini, comments: "Banks appear to be using day-to-day pricing strategies to influence consumer behavior rather than to increase revenues. For the second year running, banks are actively trying to redefine their interactions with customers, directing them towards automated channels for common operations, such as checking statement and reserving branches for more advance services like financial services advice. Many banks have raised their fees for operation at desks and cut fees for online banking and call centre services."

At the bank level, the principal attraction of retail banking seems to be the belief that its revenues are stable and thus can offset volatility in the non-retail businesses, such as corporate and commercial real estate lending, trading, and capital market activities. Some banking industry analysts go even further, claiming that retail 
banking offers high returns along with low risk. Some part of the stability in retail banking revenues may reflect natural hedges within retail banking, in other words, products or services within the business that respond differently as market conditions change (Clark et al. 2007).

The expansion of middle class in Bangladesh is a significant contributory factor towards the retail sector. Increase in consumer purchasing power coupled with more liberal attitudes towards personal loan, is contributing to Bangladesh's Retail Banking segment (Yeshmin et al., 2007). The basic differentiating factor in today's market is service quality. In general, service quality promotes customer satisfaction and stimulates intention to return (Beidokhti et al, 2008). Retail banking is the most important segment of the services provided by the private commercial banks in Bangladesh. This indicates that the private commercial banks of Bangladesh should focus more on the service quality dimensions to improve the service quality in retail banking (Bhuiyan et.al 2008).

\section{METHODOLOGY}

The methodology of the study includes the selection of sample banks, sources of data, and the method of data analysis. The present study is empirical one. The authors use literature review, primary and secondary data analysis to assess the enhancement of retail banking. Mean value is one of the important statistical techniques which is used for measuring the overall performance and growth of retail banking of the banks.

\section{Sample Selection}

28 banks are selected from 47 listed financial institutions in Dhaka Stock Exchange for conducting the study which covered $59.57 \%$ of total population.

\section{Data Collection and analysis procedure}

This study is based on secondary data. Secondary data were collected from various books, webpages, journals, articles, published literature, brochures, and the periodical reports, and annual reports of the selected banks.

The data and information have been processed and analyzed by using descriptive statistical tools in order to make the study more informative, reliable and useful. Moreover, the survey has been conducted on the basis of available information in the annual reports for 2006 to 2008. Data are analyzed on the basis of base year 2006 and shown the growth up to 2008 . 


\section{Limitations}

- The study is based on secondary data.

- Consumers' relations were not taken into considerations.

- Quantitative information of only three financial years (2006-2008) has been considered.

- The study is based on empirical evidences and several areas of asymmetry have been illuminated.

- In this study only published data in the annual reports are used.

\section{ANALYSIS AND FINDINGS}

Retail banking is the cluster of products and services that banks provide to consumers and small businesses through branches, the internet, and other channels. And each of these play an important role to measure the growth of retail banking.

To analyze the position of retail banking in 2008 of different bank the authors consider here 2006 as the base year and try to show the growth of retail banking through the year 2006 to 2008. So that, it can be clear that, in what percentage the growth occurred in every sector of retail banking.

Firstly, the number of bank branches is one of the most important indicators for finding the customers service position. The leading role of the large banking organizations in the resurgence of retail banking is reflected in the growth and redistribution of bank branches.

TABLE 1

NUMBER OF TOTAL BANK BRANCHES OPENED IN DIFFERENT YEARS

\begin{tabular}{l|c|c|c|c}
\hline & 2008 & 2007 & 2006 & Growth (\%) in 2006-2008 \\
\hline Number of branches & 1992 & 1816 & 1670 & 19.28 \\
\hline
\end{tabular}

Source: Annual Reports 2006-2008

Here, in the period between 2006-2008 the bank branches increased by 19.28 $\%$. ( Table 1). It isalso found that Pubali Bank Ltd. is going too first in this regard, having 371 branches in 2008(Appendix2).

Secondly, different products and services are offered by different banks. Here different retail deposit options, loans and card services are taken into consideration. 
Here, percentage of growth of each product is shown below that is occurred between the said years, 2006-2008.

TABLE 2

CUMULATIVE NUMBER OF RETAIL PRODUCTS OFFERED BY DIFFERENT BANKS

\begin{tabular}{lccccc}
\hline Products & 2008 & 2007 & 2006 & Growth (\%) in 2006-08 \\
\hline Deposit & 239 & 177 & 127 & $88.18 \%$ \\
Loan & 297 & 242 & 200 & $48.50 \%$ \\
Card & 63 & 56 & 52 & $21.15 \%$ \\
\hline
\end{tabular}

Source: Annual Report 2006-2008

During the period $2006-2008$ deposit products are increased by $88.18 \%$, loan products are increased by $48.50 \%$ and cards are increased by $21.15 \%$ (Table 2 ). Jamuna bank Ltd has offered highest number of deposit products that is 32 types of deposit schemes, 20 types of loans are provided by Al-Arafah Islami bank Ltd. 5 types of card services are provided by Eastern bank Ltd. in 2008 which is in highest position(Appendix 3). That means, retail products are increasing by numbers day by day only for the user of the products to give more service.

Thirdly, to deliver the services to the customers, different channels are used by the banks. Following are some channels that are famous in this regard.

TABLE 3

DIFFERENT DELIVERY CHANNELS OFFERED BY DIFFERENT BANKS

\begin{tabular}{l|l|c|c}
\hline S.L & & No. of banks offer & Percent (\%) \\
\hline 1 & ATM booth & 24 & 85.71 \\
2 & Telephone service/Phone banking & 09 & 32.14 \\
3 & Online banking service & 13 & 46.42 \\
4 & Bill paying service & 22 & 78.57 \\
5 & Brokerage & 15 & 53.57 \\
\hline
\end{tabular}

Source: Annual Report 2006-2008 
While considering the delivery channels, the authors have found that, ATM booth is offered by most of the banks and after that banks are offening bill paying service (Table 3 ).

The authors have tried to analyze the mean value of the overall performance of retail products by using the mean value and it is found that loan product is in the highest position among the retail products offered to the people by the banks (Table 4).

Figure 1: Complementary Dimensions of Retail Activities

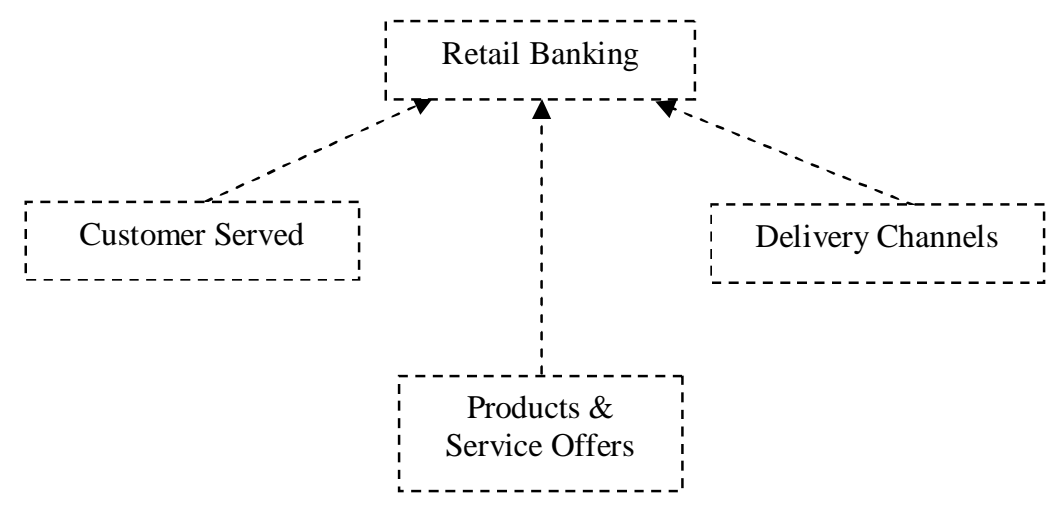

TABLE 4

MEAN VALUE OF EACH TYPE OF PRODUCT AND SERVICES OFFERS

\begin{tabular}{lccccc}
\hline & Number of banks & Minimum & Maximum & Mean \\
\hline Total loan & 28 & 16 & 44 & 27.11 \\
Total deposit & 28 & 8 & 48 & 19.39 \\
Total card service & 28 & 2 & 14 & 6.00 \\
\hline
\end{tabular}

Source: Annual Reports of Sample Banks, 2006-08

Here the authors also have found that, Jamuna bank has the highest average value on offering different retail products. After this bank, Mutual Trust Bank, South East Bank Ltd., Prime Bank, Trust Bank, One Bank, ICB Islami Bank has the next position based on the average value. National Bank Ltd, Pubali Bank Ltd, Uttara Bank Ltd. has the lowest average value on offering different retail products during the period 2006-2008 (Appendix 4). 


\section{CONCLUSION AND RECOMMENDATIONS}

The issue of RB is extremely important and contemporary. That is, it is not new phenomenon in Bangladesh. It has always been prevalent in Bangladesh in various forms In this age of tremendous development of banking industry, banks are always struggling to satisfy the consumers' escalating need. So, some recommendations may be helpful in this regard.

- Through Retail banking is becoming profitable sector of the bank; it is not mostly populated to many people who have the capacity to get the full benefit of the products. So, banks should take the chance to popularize retail banking through different promotional activities.

- Granting loan require lengthy procedure and a lot of professional and private information. Here the banks may develop some procedure to minimize the excessive formalities and can increase repayment period so that it will make the installment more convenient repayment.

- Some retail products may be introduced for the lower income level people so that they can also get the benefit of bank's different retail products within their limited income.

- Information about the retail banking should be more conveyed and the way of getting the service should be made simple and easy.

- Banks should provide wide range of service so that customer can full time connect with the bank.

- Bank can emphasize more on the retail sector and can enlarge their basket of retail products identifying various service segments accompanying with modern technology like electronic banking, online banking etc.

- Increase the number of booths and branches for easy transactions in geographically profitable locations.

- More information about the retail products and their benefit should be provided in the websites of the bank.

- Annul reports of the bank may show more detailed information about the retail products showing the performance of the products in every year.

Now a day's retail banking has been an important area of strategic focus and it is significant because of the role of the very largest banks. By developing product differentiations, innovation and business process reengineering, maximum use of the opportunities, banks can enhance the running process of retail banking in the banking industry and can find a vital place for it. 


\section{REFERENCES}

Ahmed, Salahuddin, Dilli Raj Khanal (2007) "Service Trade in Developing Asia: A Case Study of the Banking and Insurance Sectors in Bangladesh" Asia-Pacific Research and Training Network on Trade Working Paper series, No.38, July 2007.

Beidokhti, Dr. A. Amin, Dr. A. H. Rezia, M. A. Saboorynia and Mohammad Abdolshah (2008), "Prioritizing the Main Influencer Factors of Service Quality by Using the Hysteresis Model; A Case Study On Retail Banking", $21^{\text {st }}$ Australasian Finance and Banking Conference.

Business Week, 1994. “Another Year in 'Bank Heaven'?” January 10.

Bhuiyan, Md. Tabarak Hossain, Nazrul Islam and Jashim uddin Ahmed (2008), "Service Quality in Retail Banking of Private Commercial Banks in Bangladesh", International Conference on Global Commerce, Energy Minerals, and the Environment(organized by Global Commerce Forum, Arvada), October 20-22-2008.

Cressey, P. and Scott, P. (1992), "Employment, Technology and Industrial Relations in the UK Clearing Banks: Is The Honeymoon Over?" New Technology, Work and Employment 3 83-96

Cassettari, S. (1994), "Geography is the Key” The Banker, November 93

DeYoung, R., and T. Rice. 2004. "How Do Banks Make Money? A Variety of Business Strategies." Federal Reserve Bank of Chicago Economic Perspectives 28, fourth quarter: 52-68.

Delvin, J. (1995), "Technology and Innovation in Retail Banking Distribution." International Journal of Bank Marketing, 13, 19-25.

Gopinath, Shyamala (2005) "Retail Banking-Opportunities and Challenges", The IBA Banking Frontiers International Conference on "Retail Banking Directions: Opportunities \& Challenges", Mumbai, 28 May 2005.

Hirtle, Beverly J. and Kevin J.Stiroh (2005), "The return to Retail and the Performence of U.S.Banks", URL http://www.ssrn.com/abstract=id873848.pdf

Kennington, C., Hill, J. \& Rakowska, A. (1996), "Consumer selection criteria for banks in Poland”. International Journal of Bank Marketing, 14, 12-21.

Leyshon, A. and Thrift, N. (1999), "Lists Come Alive: Electronic Systems of Knowledge and the Rise of Credit Scoring in Retail Banking." Economy and Society 28 434-66

Moody's Investors Service. 2003. "Moody's Remains Upbeat on U.S. Banks' Ratings." June.

Pollard, J. S. (1995), "Industry change and labor segmentation: the banking industry in Los Angeles 1970-1990' Ph.D. Dissertation, Graduate School of Architecture and Urban Planning, University of California, Los Angeles, USA

Pollard, J. S. (1996), "Banking at the Margins: A Geography of Financial Exclusion in Los Angeles" Environment and Planning A28 1209-32

Smith, C. P. (1993), " Servicing the Coke culture” The Banker February 22-24 
Standard and Poor's. 2004. "Retail Sector Anchors Large Complex Banks in U.S." October 4.

Stiroh, K. J. 2004. "Diversification in Banking: Is Noninterest Income the Answer?" Journal of Money, Credit, and Banking 36, no. 5 (October): 853-82.

Talmor, S. (1994), “After you” The Banker March 74-76

Yeshmin, Farjana, Farjana Afrin and Ishrat Jahan Tania (2007), “An Empirical Study on the Problems and Prospects of Retail Banking Operation in Bangladesh", Center for Socioeconomic Research, ASA University Review, Volume 1, No. 1( $1^{\text {st }}$ Issue $)$, JulyDecember, 2007.

Zineldin, M. (1996), "Bank Strategic Positioning and Some Determinants of Bank Selection." International Journal of Bank Marketing, 14, 12-22.

\section{APPENDICES}

\section{APPENDIX-1}

\section{LIST OF DIFFERENT RETAIL PRODUCTS OFFERED BY DIFFERENT BANKS}

Deposits Deposit Pension Scheme, Monthly benefit/profit scheme, Education Savings scheme ,Deposit double scheme, Marriage saving scheme, Lakopati scheme, Millionere scheme, Hajj saving scheme, House deposit scheme, Smart Plant/Smart savers plan, Junior saving scheme, 3 stages saving scheme, Muhor saving scheme, Family maintenance scheme, Brick by Brick scheme, Holiday savings plan, Income unlimited, Cash waqf, Premire 50+ account, Premire genius account, Mudaraba multiplus savings scheme, Mudaraba monthly profit deposit scheme,Ananta account,FD Chamak, Abashon deposit scheme, Student's saving scheme, Car deposit scheme, Travel deposit scheme, Money multiplier, Quarterly benefit scheme, Daily profit savings account, Sangshar deposit scheme, Easy account, Hi-Fi-FDR, Overseas Earner's deposit scheme, House hold Durable deposit scheme, Jamuna bank paribar, Tripple growth deposit scheme etc.

Loans Car loan, SME (Small and Medium Enterprise), Home Loan, Household durable loans Personal Loan, Education Loan, Doctors loan, Travel Loan, Consumer finance/ consumer credit scheme, Marriage loan, Rural Development, Salary loan / Advanced against salary, CNG conversion loan, Vacation loan, Mortgage loan, Teachers loan, Fast cash, Loan for woman, Personal installment loan, Flexi loan, Lease financiag, Hospitalization loan, Top-up loan, Utshab Loan, Gold grace, Peshajibi loan, Small loan scheme, Home\&office renovation loan, Education loan, Auto loan, Easy loan for executive, Gold grace, Corporate finance, Commercial finance, Industrial finance, Project finance, Syndicate finance, Hire purchase finance, Real estate finance etc.

Card services ATM card / Debit card, Credit card, Dual card, Prepaid card, Lifestyle card, Cool card, Gift card, Hajj card, Travel card etc. 
APPENDIX 2

BANK BRANCHES ARE OPENED IN DIFFERENT YEARS

\begin{tabular}{|c|c|c|c|c|}
\hline Name of the banks & 2008 & 2007 & 2006 & Growth $(\%)$ \\
\hline Prime Bank Ltd. (PBL) & 70 & 61 & 50 & 40 \\
\hline The City Bank Ltd.(TCBL) & 83 & 83 & 78 & 6.4 \\
\hline Islami Bank Ltd (IBBL) & 206 & 186 & 176 & 14.56 \\
\hline Dhaka Bank Ltd. (DBL) & 44 & 41 & 38 & 13.63 \\
\hline Mutual trust Bank Ltd. (MTBL) & 36 & 30 & 25 & 44 \\
\hline South east Bank Ltd (SEBL) & 46 & 38 & 31 & 48.38 \\
\hline Premier Bank Ltd & 30 & 27 & 26 & 15.38 \\
\hline Trust Bank Ltd & 45 & 31 & 26 & 42.22 \\
\hline National Credit and Commerce Bank Ltd (NCC) & 57 & 53 & 48 & 18.75 \\
\hline Dutch Bangla Bank Ltd (DBBL) & 64 & 49 & 39 & 64.10 \\
\hline Pubali bank Ltd & 371 & 361 & 356 & 4.21 \\
\hline Mercantile Bank Ltd (MBL) & 42 & 41 & 35 & 20 \\
\hline Bank Asia Ltd & 33 & 30 & 24 & 37.5 \\
\hline BRAC Bank Ltd & 56 & 36 & 26 & 115.38 \\
\hline One Bank Ltd & 32 & 30 & 23 & 39.13 \\
\hline National Bank Ltd (NBL) & 106 & 101 & 91 & 16.48 \\
\hline IFIC Bank Ltd. & 74 & 69 & 65 & 13.84 \\
\hline Eastern Bank Ltd.(EBL) & 34 & 28 & 25 & 36 \\
\hline Jamuna Bank Ltd & 39 & 35 & 29 & 34.48 \\
\hline First Security Bank Ltd (FSBL) & 29 & 20 & 15 & 93.33 \\
\hline Uttara Bank ltd. & 207 & 207 & 201 & 2.98 \\
\hline Shahajalal Bank ltd. & 33 & 26 & 21 & 57.14 \\
\hline AB Bank & 72 & 71 & 68 & 5.88 \\
\hline ICB Islami Bank Ltd. & 31 & 28 & 28 & 10.71 \\
\hline Al-Arafah Bank Ltd. & 50 & 46 & 46 & 8.69 \\
\hline Social Islami Bank Ltd. & 28 & 24 & 24 & 16.66 \\
\hline Standard Bank Ltd. & 32 & 29 & 26 & 23.07 \\
\hline Exim Bank Ltd. & 42 & 35 & 30 & 40 \\
\hline Total & 1992 & 1816 & 1670 & -- \\
\hline
\end{tabular}


APPENDIX 3

\section{LIST OF DIFFERENT RETAIL PRODUCTS OFFERED} BY DIFFERENT BANKS (2006-2008)

\begin{tabular}{|c|c|c|c|c|c|c|c|c|c|c|c|c|}
\hline \multirow[t]{2}{*}{ Name of the banks } & \multicolumn{3}{|c|}{ Deposit } & \multirow{2}{*}{$\begin{array}{c}\text { Growth } \\
\%\end{array}$} & \multicolumn{3}{|c|}{ loans } & \multirow{2}{*}{$\begin{array}{c}\text { Growth } \\
\%\end{array}$} & \multicolumn{3}{|c|}{ Card service } & \multirow{2}{*}{$\begin{array}{c}\text { Growth } \\
\%\end{array}$} \\
\hline & 2008 & 2007 & 2006 & & 2008 & 2007 & 2006 & & 2008 & 2007 & 2006 & \\
\hline PBL & 9 & 9 & 7 & 28 & 11 & 11 & 12 & (8) & 2 & 2 & 2 & 0 \\
\hline TCBL & 13 & 12 & 7 & 85 & 13 & 4 & 01 & 1200 & 2 & 2 & 2 & 0 \\
\hline IBBL & 18 & 7 & 4 & 350 & 6 & 6 & 06 & 0 & 1 & 1 & 1 & 0 \\
\hline DBL & 5 & 5 & 6 & (16) & 6 & 5 & 05 & 20 & 2 & 2 & 2 & 0 \\
\hline MTBL & 11 & 11 & 5 & 120 & 16 & 13 & 05 & 220 & 3 & 3 & 3 & 0 \\
\hline SEBL & 7 & 4 & 5 & 40 & 16 & 14 & 13 & 23 & 3 & 3 & 2 & 50 \\
\hline NCC & 6 & 6 & 1 & 500 & 10 & 7 & 5 & 100 & 1 & 1 & 1 & 0 \\
\hline DBBL & 4 & 4 & 3 & 33 & 9 & 5 & 5 & 80 & 2 & 2 & 2 & 0 \\
\hline MBL & 6 & 6 & 3 & 100 & 11 & 11 & 10 & 10 & 3 & 3 & 3 & 0 \\
\hline BankAsia & 3 & 3 & 3 & 0 & 14 & 16 & 7 & 100 & 4 & 3 & 2 & 100 \\
\hline BRAC bank & 11 & 11 & 2 & 450 & 5 & 5 & 11 & $(120)$ & 2 & 2 & 2 & 0 \\
\hline Onebank & 6 & 6 & 1 & 500 & 18 & 18 & 8 & 125 & 2 & 2 & 2 & 0 \\
\hline Nationalbank & 6 & 2 & 2 & 200 & 8 & 5 & 5 & 60 & 2 & 2 & 1 & 100 \\
\hline IFIC bank & 4 & 3 & 1 & 300 & 13 & 12 & 07 & 85 & 3 & 1 & 1 & 200 \\
\hline EasternBank & 6 & 2 & 1 & 500 & 10 & 5 & 8 & 25 & 5 & 5 & 4 & 25 \\
\hline JamunaBank & 32 & 9 & 7 & 357 & 11 & 11 & 4 & 175 & 3 & 2 & 02 & 50 \\
\hline First security bank & 5 & 5 & 5 & 0 & 7 & 7 & 7 & 0 & 1 & 1 & 1 & 0 \\
\hline AB bank & 4 & 4 & 4 & 0 & 12 & 6 & 08 & 50 & 02 & 2 & 2 & 0 \\
\hline Pubali bank & 4 & 3 & 3 & 25 & 4 & 4 & 4 & 0 & 3 & 2 & 2 & 33 \\
\hline Uttara Bank & 4 & 3 & 2 & 100 & 9 & 9 & 7 & 28 & 1 & 1 & 0 & 100 \\
\hline Al-Arafah Islami bank & 16 & 6 & 6 & 166 & 20 & 9 & 1 & 1900 & 1 & 1 & 1 & 0 \\
\hline SIBL & 11 & 9 & 8 & 37.5 & 6 & 4 & 4 & 50 & 2 & 2 & 2 & 0 \\
\hline Standardbank & 6 & 6 & 6 & 0 & 8 & 7 & 7 & 14 & 1 & 1 & 1 & 0 \\
\hline Exim bank & 5 & 7 & 8 & $(37.5)$ & 8 & 8 & 8 & 0 & 3 & 2 & 3 & 0 \\
\hline ICB Islami bank & 10 & 10 & 10 & 0 & 10 & 10 & 10 & 0 & 1 & 1 & 1 & 0 \\
\hline Premierbank & 9 & 4 & 4 & 55 & 11 & 13 & 13 & (18) & 2 & 2 & 2 & 0 \\
\hline Trust & 7 & 9 & 9 & 28 & 11 & 11 & 11 & 0 & 2 & 2 & 2 & 0 \\
\hline Shahajalal & 11 & 7 & 4 & 175 & 14 & 6 & 8 & 75 & 4 & 3 & 3 & 33 \\
\hline Total & 239 & 177 & 127 & -- & 297 & 242 & 200 & -- & 63 & 56 & 52 & -- \\
\hline
\end{tabular}


APPENDIX 4

AVERAGE RETAIL PRODUCTS SERVICES PROVIDED BY BANKS DURING 2006 TO2008

\begin{tabular}{|c|c|c|c|c|c|}
\hline Name of banks & Deposits & Loans & Card service & Total & Average \\
\hline PBL & 25 & 34 & 6 & 65 & 21.66 \\
\hline TCBL & 32 & 18 & 6 & 56 & 18.66 \\
\hline IBBL & 29 & 18 & 3 & 50 & 16.66 \\
\hline DBL & 16 & 16 & 6 & 38 & 12.66 \\
\hline MTBL & 27 & 34 & 9 & 70 & 23.33 \\
\hline SEBL & 16 & 43 & 8 & 67 & 22.33 \\
\hline $\mathrm{NCC}$ & 13 & 22 & 3 & 38 & 12.66 \\
\hline DBBL & 11 & 19 & 6 & 36 & 12 \\
\hline MBL & 15 & 32 & 9 & 56 & 18.66 \\
\hline Bank Asia & 9 & 37 & 9 & 55 & 18.33 \\
\hline Brac bank & 24 & 21 & 6 & 51 & 17 \\
\hline One bank & 13 & 44 & 6 & 63 & 21 \\
\hline National bank & 10 & 18 & 5 & 33 & 11 \\
\hline IFIC bank & 8 & 32 & 5 & 45 & 15 \\
\hline Eastern bank & 9 & 23 & 14 & 46 & 15.33 \\
\hline Jamuna & 48 & 26 & 7 & 81 & 27 \\
\hline Fiest Security bank & 15 & 21 & 3 & 39 & 13 \\
\hline AB bank & 16 & 26 & 6 & 48 & 16 \\
\hline ICB Islami bank & 30 & 30 & 3 & 63 & 21 \\
\hline Pubali bank & 10 & 16 & 7 & 33 & 11 \\
\hline Uttara bank & 9 & 25 & 2 & 36 & 12 \\
\hline Al-Arafah bank & 28 & 30 & 3 & 61 & 20.33 \\
\hline SIBL & 28 & 30 & 3 & 48 & 16 \\
\hline Standard bank & 18 & 22 & 3 & 43 & 14.33 \\
\hline Exim bank & 20 & 24 & 8 & 52 & 17.33 \\
\hline Premire bank & 17 & 37 & 6 & 60 & 20 \\
\hline Trust bank & 25 & 33 & 6 & 64 & 21.33 \\
\hline Shahjalal bank & 22 & 28 & 10 & 60 & 20 \\
\hline
\end{tabular}

